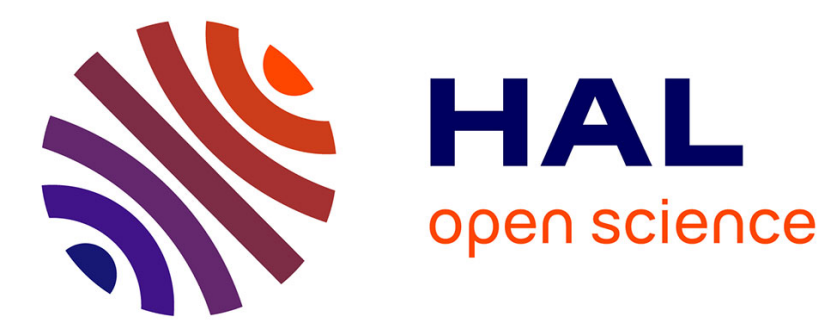

\title{
Direct and indirect electrochemical reduction prior to a biological treatment for dimetridazole removal
}

\author{
Melika Zaghdoudi, Florence Fourcade, Isabelle Soutrel, Didier Floner, \\ Abdeltif Amrane, Hager Maghraoui-Meherzi, Florence Geneste
}

\section{- To cite this version:}

Melika Zaghdoudi, Florence Fourcade, Isabelle Soutrel, Didier Floner, Abdeltif Amrane, et al.. Direct and indirect electrochemical reduction prior to a biological treatment for dimetridazole removal. Journal of Hazardous Materials, 2017, 335, pp.10-17. 10.1016/j.jhazmat.2017.04.028 hal-01533327

HAL Id: hal-01533327

https://hal-univ-rennes1.archives-ouvertes.fr/hal-01533327

Submitted on $13 \mathrm{Jul} 2017$

HAL is a multi-disciplinary open access archive for the deposit and dissemination of scientific research documents, whether they are published or not. The documents may come from teaching and research institutions in France or abroad, or from public or private research centers.
L'archive ouverte pluridisciplinaire HAL, est destinée au dépôt et à la diffusion de documents scientifiques de niveau recherche, publiés ou non, émanant des établissements d'enseignement et de recherche français ou étrangers, des laboratoires publics ou privés. 


\section{Direct and indirect electrochemical reduction prior to a biological treatment for dimetridazole removal}

Melika Zaghdoudi ${ }^{\mathrm{a}, \mathrm{b}, \mathrm{c}}$, Florence Fourcade $^{\mathrm{b}}$, Isabelle Soutrel ${ }^{\mathrm{b}}$, Didier Floner ${ }^{\mathrm{a}}$, , Abdeltif Amrane $^{\mathrm{b} *}$, Hager Maghraoui-Meherzi ${ }^{\mathrm{c}}$, Florence Geneste $^{\mathrm{a} *}$

a) Institut des Sciences Chimiques de Rennes, Université de Rennes 1, UMR-CNRS 6226, Equipe MaCSE, Campus de Beaulieu, 35042 Rennes Cedex, France.

b) Institut des Sciences Chimiques de Rennes, Université de Rennes 1, Ecole Nationale Supérieure de Chimie de Rennes, UMR-CNRS 6226, 11 allée de Beaulieu, CS 50837, 3570 Renne Cedex 7, France.

c) Université de Tunis El Manar, Faculté des Sciences de Tunis, LR99ES15 Laboratoire de Chimie Analytique et d'Electrochimie, 2092, Tunis, Tunisie

*Corresponding email: florence.geneste@ univ-rennes1.fr; phone: +33 22323 59 65; Fax: +33 2232367 97, email: abdeltif.amrane@ univ-rennes1.fr; phone: + 3322323 81 55; Fax: +33223238120

Graphical Abstract 


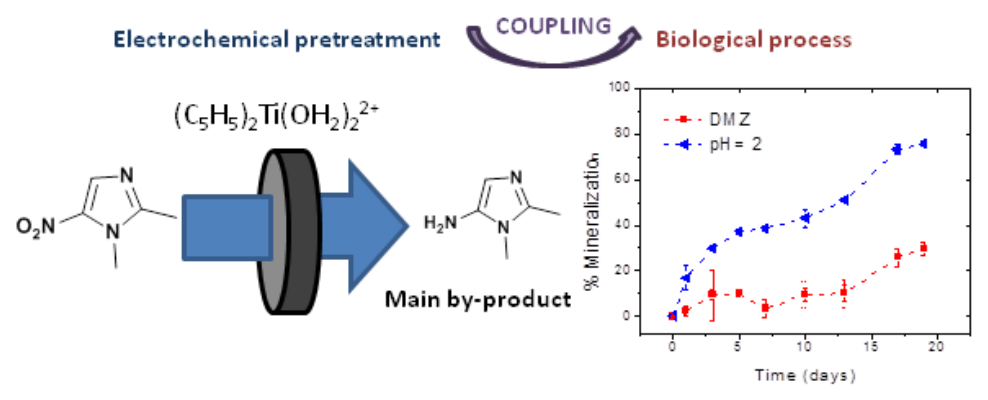

Highlights

- Treatment of dimetridazole, a biorecalcitrant antibiotic, by a coupling process

- Improved selectivity for the electroreduction of dimetridazole into its amino derivative

- Enhancement of the biodegradability by catalytic reduction with titanocene

- Efficiency of the coupling process with high mineralization yields

\section{ABSTRACT}

Two different electrochemical reduction processes for the removal of dimetridazole, a nitroimidazole-based antibiotic, were examined in this work. A direct electrochemical reduction was first carried out in a home-made flow cell in acidic medium at potentials chosen to minimize the formation of amino derivatives and then the formation of azo dimer. Analysis of the electrolyzed solution showed a total degradation of dimetridazole and the $\mathrm{BOD}_{5} / \mathrm{COD}$ ratio increased from 0.13 to 0.24 . An indirect electrochemical reduction in the presence of titanocene dichloride $\left(\left(\mathrm{C}_{5} \mathrm{H}_{5}\right)_{2} \mathrm{TiCl}_{2}\right)$, which is used to reduce selectively nitro compounds, was then investigated to favour the formation of amino compounds over hydroxylamines and then to prevent the formation of azo and azoxy dimers. UPLC-MS/MS analyses showed a higher selectivity towards the formation of the amino compound for indirect electrolyses performed at $\mathrm{pH}$ 2. To confirm the effectiveness of the electrochemical reduction, a biological treatment 
involving activated sludge was then carried out after direct and indirect electrolyses at different $\mathrm{pH}$. The enhancement of the biodegradability was clearly shown since mineralization yields of all electrolyzed solutions increased significantly.

Keywords: Dimetridazole; Electrochemical reduction; Titanium complex; Biological treatment; coupling process

\section{Introduction}

Pharmaceuticals constitute a large group of bioactive chemicals used in humans and animals for disease treatment, prevention and growth promotion. Over the last twenty years, the occurrence of pharmaceuticals in water resources has been considered as a worrying environmental issue. These pseudo-persistent compounds can cause ecotoxicological risk due to their potential long-term negative effects in living organism even at trace concentrations [1]. Pharmaceuticals end up in the aquatic system from various sources including municipal [2], hospital [3], agriculture [4] and industrial effluents [5]. Conventional wastewater treatment plants (WWTPs) are source of contamination because they are not directed to remove polar and soluble compounds [6]. Pharmaceuticals have been detected in different aquatic matrices: ground and surface water [7, 8] and drinking water [9]. In several developed countries they have been detected in tap water at levels of usually $<100 \mathrm{ng} / \mathrm{L}$. These large polluted volumes are difficult to treat. One solution would be therefore to treat this pollution at source, namely to treat specific industrial (chemical and pharmaceutical) effluents, which can contain concentrations and COD (Chemical Oxygen Demand) higher than 1 and $10 \mathrm{~g} \mathrm{~L}^{-1}$ respectively for instance [10] or hospital effluents after concentration by membrane process[11].

Due to their non-biodegradability and high solubility in water [12], a wide variety of processes have been investigated for the removal of pharmaceuticals from water systems. Physical techniques such as adsorption [13] and membrane technologies [14] have been applied. These techniques require posttreatment processes because the pollutant is only transferred to another phase [15]. Advanced Oxidation Processes (AOPs), based on the generation of hydroxyl radicals $\mathrm{OH}^{*}$, a very reactive, non-selective and powerful oxidizing agent, have proved to be efficient for the elimination of most organic molecules [1]. Due to a relatively high operating cost of AOPs, combining chemical pretreatment and a biological process was previously investigated. Thus anodic oxidation [16], electro-Fenton [10, 17, 18], photo-Fenton [19] and photo-catalysis [20] were reported as possible pretreatments. Although complete mineralisation 
of the pollutant can be achieved, AOPs can produce by-products of higher toxicity at the beginning of treatment due to the non-selectivity of the processes.

Nitroimidazoles are antibiotics widely used to treat infections caused by anaerobic and protozoan bacteria (e.g. Trichomonas vaginalis and Giardia lamblia) in human and animals. They are added to chow for fish and fowl leading to their accumulation in animals, fish farm waters and meat industry effluents [21].

Dimetridazole 1 (DMZ, 1, 2- dimethyl-5-nitroimidazole) belongs to nitroimidazole drugs (Table 1). Because DMZ is now believed to possess genotoxic, carcinogenic and mutagenic side effects, many countries, including European Union (Commission Regulation (EC) No. 1798/95, 1995), United States (Animal Medicinal Drug Use Clarification Act of, 1994), and China (The circular of the Chinese Ministry of Agriculture, 2002), has banned its use in food producing animals. However, residual concentration of DMZ has been detected in surface and tap water in some regions (median-maximum, 6.9-14.7 ng/L) [22]. DMZ removal has been studied through different methods including photo-degradation [21], adsorption and biosorption on activated carbon [23]. Fungal treatment of non-sterile veterinary hospital effluent was also investigated in which no significant removal of dimetridazole was reported [24].

\subsubsection{Electrochemical analysis}

Electrochemical analysis of DMZ and electrolyzed solutions were performed using a conventional three-electrode cell with a glassy carbon electrode $\left(7 \mathrm{~mm}^{2}\right)$ as working electrode, a platinum wire as counter electrode and a saturated calomel electrode (SCE) as reference electrode. Experiments were performed at room temperature under argon atmosphere. Voltammograms were obtained using a potentiostat (Princeton Applied Research, EG\&G 362). The glassy carbon electrode was thoroughly polished with Struers Waterproof silicon carbide paper before each experiment.

\subsubsection{Ultra performance liquid chromatography-tandem mass spectrometer (UPLC-MS/MS) method}

DMZ and its by-products were separated using a Waters Acquity UPLC system (Waters, Manchester, UK) composed of an Acquity UPLC binary solvent manager, an Acquity UPLC sample manager and an Acquity UPLC column heater equipped with a Waters Acquity UPLC BEH C-18 column $(2.1 \mathrm{~mm} \times 100 \mathrm{~mm} ; 1.7 \mu \mathrm{m})$ (Milford, MA, USA). Gradient LC elution was performed in acetonitrile with $0.1 \%$ formic acid as mobile phase A and acetonitrile/ultra-pure water $(10 / 90, \mathrm{v} / \mathrm{v})$ with $0.1 \%$ formic acid as mobile phase B. Separation of the analytes on the 
column was performed with a gradient of phase A/phase B at $400 \mu 1 / \mathrm{min}^{-1}$. The starting eluent composition consisted of $0 \% \mathrm{~A} / 100 \% \mathrm{~B}$ for $1 \mathrm{~min}$ then the proportion of solvent A increased linearly to reach $100 \%$ in $8 \mathrm{~min}$ and then returned to the initial conditions in $3 \mathrm{~min}$.

A Quattro Premier triple-quadripole mass spectrometer (Manchester, UK) was used for byproducts detection. It was operated with an electrospray source in positive ionisation mode with a cone potential of $25 \mathrm{~V}$. Source conditions were capillary voltage $3 \mathrm{kv}$, source temperature $120^{\circ} \mathrm{C}$ and desolvation temperature $350^{\circ} \mathrm{C}$. The cone and desolvation gas flow $\left(\mathrm{N}_{2}\right)$ were 50 and $750 \mathrm{~L} \mathrm{~h}^{-1}$, respectively. Analyses were performed in full scan mode and spectra were acquired between 90 and $500 \mathrm{~m} / \mathrm{z}$. The acquisitions were made in SIR mode for the following m/z: 112, 142, 219, 235 and data were treated with Micromass MassLynx 4.1 software.

\subsubsection{High pressure liquid chromatography (HPLC)}

DMZ concentration was measured by HPLC using a Waters 996 system equipped with Waters 996 Photodiode Array Detector and Waters 600 LCD Pump. The separation was achieved on Waters C-18 (4.6 $\mathrm{mm} \times 250 \mathrm{~mm} ; 5 \mu \mathrm{m})$ reversed-phase. The mobile phase consisted of a mixture of acetonitrile/ultra-pure water $(5 / 95, \mathrm{v} / \mathrm{v})+0.1 \%$ formic acid. The flow rate was set at $1 \mathrm{ml} \mathrm{min}{ }^{-1}$ and $20 \mu \mathrm{L}$ injections were considered. The detection of DMZ was carried out at 320 $\mathrm{nm}$ and the retention time was approximately $1.4 \mathrm{~min}$.

\subsubsection{Total organic carbon (TOC)}

TOC was measured by means of TOC- $\mathrm{V}_{\mathrm{CPH} / \mathrm{CPN}}$ Total Organic Analyzer Schimadzu as previously reported [27].

\subsubsection{Chemical Oxygen Demand (COD) measurements}

COD was measured by means of a Nanocolor ${ }^{\circledR}$ Test CSB 160 from Macherey- Nagel (Düren, Germany). The amount of oxygen required for the oxidation of the organic and mineral matter at $148^{\circ} \mathrm{C}$ for 2 hours was quantified after oxidation with $\mathrm{K}_{2} \mathrm{Cr}_{2} \mathrm{O}_{7}$ at acidic $\mathrm{pH}$ and heating. Measurements were carried out at $436 \mathrm{~nm}$. For each sample, each measurement was duplicated.

\subsubsection{Biological Oxygen Demand (BOD 5 ) measurements}

$\mathrm{BOD}_{5}$ was carried by the Test Nanocolor ${ }^{\circledR}$ BOD $_{5}-\mathrm{TT}$ Test 8-25 from Macherey- Nagel (Düren, Germany). This test allows a simplified determination of biological oxygen demand of diluted samples. Activated sludge provided by a local wastewater treatment plant (Rennes Beaurade, France) was used to inoculate the test tubes. The microbial concentration was $0.05 \mathrm{~g} \mathrm{~L}^{-1}$. Tests tubes were always duplicated. Measurements of dissolved oxygen were carried out after 5 days 
of incubation at $20 \pm 1{ }^{\circ} \mathrm{C}$ in the dark according to the method of Winkler EN25813 - G21 by photometric evaluation of iodine colour [33].

\section{Results and discussion}

\subsection{Cyclic voltammetry analysis of dimetridazole}

\subsubsection{Electrochemical behaviour of dimetridazole in $0.5 \mathrm{M} \mathrm{H}_{2} \mathrm{SO}_{4}$}

Cyclic voltammetry was used to investigate the electrochemical behaviour of DMZ (100 $\mathrm{mg} \mathrm{L}^{-}$ $\left.{ }^{1}\right)$ on a glassy carbon electrode in acidic medium $\left(0.5 \mathrm{M} \mathrm{H}_{2} \mathrm{SO}_{4}\right)$. As presented in Fig. 1, the voltammogram showed a single reduction peak of DMZ at $-0.35 \mathrm{~V} / \mathrm{SCE}$. This peak was attributed to the four-electron reduction of nitro group of the heteroaromatic nitro compound to the corresponding hydroxylamine derivative according to the following equation (Eq. (3)) [34].<smiles>Cc1ncc([N+](=O)[O-])n1C</smiles>

Whereas the reduction of hydroxylamine into amine is known to happen in strong acidic medium, no peak corresponding to this reduction process (Eq. (4)) was observed on the voltammogram, probably hidden by hydrogen evolution occurring at low negative potentials on glassy carbon electrode in acidic medium [35].<smiles>Cc1ncc(N)n1C</smiles>

\subsubsection{Electroreduction of DMZ at different $p H$}

Electrochemical reduction of DMZ is a complex process; indeed, the mechanism of nitro group reduction depends on the nature of the electrode and the medium (solvents, supporting electrolyte and $\mathrm{pH}$ ) [36]. Cyclic voltammetry was used to investigate the effect of $\mathrm{pH}$ on the electrochemical reduction of DMZ $\left(100 \mathrm{mg} \mathrm{L}^{-1}\right)$ on a glassy carbon electrode. As presented in Fig. 2, when the initial $\mathrm{pH}$ increased from $0.3\left(0.5 \mathrm{M} \mathrm{H}_{2} \mathrm{SO}_{4}\right)$ to 3 by adding $\mathrm{NaOH}$ solution, the reduction potential of $\mathrm{DMZ}$ decreased from -0.35 to $-0.55 \mathrm{~V} / \mathrm{SCE}$. This is consistent with the mechanism of reduction of the nitro group into hydroxylamine (Eq. (3)) involving four protons and four electrons $(-60 \mathrm{mV} / \mathrm{pH})$. However, a decrease of the peak was observed at $\mathrm{pH}$ 3, which can be attributed to a poor solubility of DMZ in this medium [37].

\subsection{Direct electrolysis of DMZ}


Direct electrolysis of DMZ (100 mg L $\left.\mathrm{m}^{-1}\right)$ was carried out in acidic medium $\mathrm{H}_{2} \mathrm{SO}_{4}(0.5 \mathrm{M})$ in a flow electrochemical cell, at a flow rate of $1 \mathrm{~mL} \mathrm{~min}^{-1}$. The media was constantly saturated with argon to avoid any influence of the dissolved oxygen. To minimize the formation of amine (and then the formation of azo dimer) usually occurring at the potential of hydrogen evolution, a low negative potential (-0.45 V/SCE) was considered.

\subsubsection{DMZ degradation}

After a single pass through the flow cell, electrolyzed solution was analyzed by UPLC to measure the residual concentration of DMZ. UPLC analysis showed a disappearance of DMZ (conversion yield $=99.5 \%$ ). To examine by-products formation, the electrolyzed solution was also analyzed by UPLC-MS/MS, showing the presence of five main by-products. Two of them could not be identified, at $0.77 \mathrm{~min}\left(\mathrm{MH}^{+} 172\right)$ and at $1.1 \mathrm{~min}\left(\mathrm{MH}^{+} 100\right)$; while the three others, namely at $0.63 \mathrm{~min}\left(\mathrm{MH}^{+} 112\right), 1.36 \mathrm{~min}\left(\mathrm{MH}^{+} 219\right)$, and $0.87\left(\mathrm{MH}^{+} 235\right)$ were identified. The first one corresponded to the protonated amine 2 and the two others to azo $\left(\mathrm{MH}^{+} 219\right)$ and azoxy $\left(\mathrm{MH}^{+} 235\right)$ dimers 3 and $\mathbf{4}$, as shown in Scheme 2.<smiles>Cc1ncc([NH3+])n1C</smiles>

$\mathrm{MH}^{+} 112$

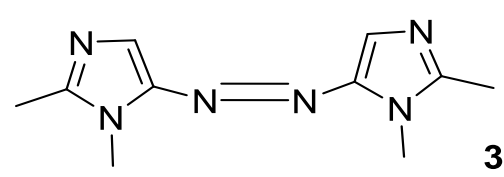

$\mathrm{MH}^{+} 219$

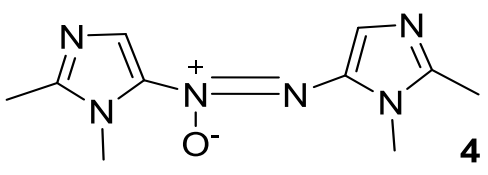

$\mathrm{MH}^{+} 235$

Scheme 2. Chemical structures of identified degradation by-products

Thus, a potential of $-0.45 \mathrm{~V} / \mathrm{SCE}$ for the reduction of DMZ did not totally prevent at $\mathrm{pH}=0.3$ the formation of the amine and so of the azo dimer 3.

Direct electrolysis of DMZ (100 mg L $\left.{ }^{-1}\right)$ was also investigated in acidic medium $\mathrm{H}_{2} \mathrm{SO}_{4}(0.5$ $\mathrm{M})$ at less negative potential (-0.3 V/SCE). Analysis by UPLC showed a low conversion yield (76.09\%) and UPLC-MS/MS indicate that the formation of amine 2 and azo dimer 3 still occurred.

\subsubsection{Biodegradability evaluation}

In order to assess the biodegradability of both DMZ $\left(100 \mathrm{mg} \mathrm{L}^{-1}\right)$ and its electrolyzed solutions, $\mathrm{BOD}_{5}$ and $\mathrm{COD}$ values were measured. An effluent can be considered as easily biodegradable if its $\mathrm{BOD}_{5} / \mathrm{COD}$ ratio exceeds 0.4 [36]. As presented in Table 2, this ratio increased from 0.13 before electrolysis to 0.24 after electrolysis, showing an increase of the effluent's biodegradability. Even if the limit of biodegradability was not reached, its increase indicated that a biological treatment after the electrochemical reduction could be envisaged. 


\subsection{Indirect electroreduction of dimetridazole}

Indirect electroreduction of dimetridazole was performed with a titanocene complex used as catalyst. Indeed, titanocene dichloride is known to undergo spontaneous hydrolysis in acidic medium giving rise to the oxidized form of the catalyst $\left(\mathrm{C}_{5} \mathrm{H}_{5}\right)_{2} \mathrm{Ti}\left(\mathrm{OH}_{2}\right)_{2}{ }^{2+}[38,39]$. It can then be electrochemically reduced into its active form $\left(\mathrm{C}_{5} \mathrm{H}_{5}\right)_{2} \mathrm{Ti}\left(\mathrm{OH}_{2}\right)_{2}{ }^{+}$(Eq. (5)).

$$
\left(\mathrm{C}_{5} \mathrm{H}_{5}\right)_{2} \mathrm{Ti}\left(\mathrm{OH}_{2}\right)_{2}^{+} \rightleftharpoons\left(\mathrm{C}_{5} \mathrm{H}_{5}\right)_{2} \mathrm{Ti}\left(\mathrm{OH}_{2}\right)_{2}^{2+}+\mathrm{e}^{-}
$$

$\left(\mathrm{C}_{5} \mathrm{H}_{5}\right)_{2} \mathrm{Ti}\left(\mathrm{OH}_{2}\right)_{2}{ }^{+}$is able to perform a six-electron reduction of nitro compounds without the formation of a hydroxylamine intermediate as occurring in direct cathodic reduction (Eq. (6)).

$$
6\left(\mathrm{C}_{5} \mathrm{H}_{5}\right)_{2} \mathrm{Ti}\left(\mathrm{OH}_{2}\right)_{2}{ }^{+}+\mathrm{RNO}_{2}+7 \mathrm{H}^{+} \longrightarrow 6\left(\mathrm{C}_{5} \mathrm{H}_{5}\right)_{2} \mathrm{Ti}\left(\mathrm{OH}_{2}\right)_{2}{ }^{2+}+\mathrm{RNH}_{3}{ }^{+}+2 \mathrm{H}_{2} \mathrm{O}
$$

\subsubsection{Catalytic activity of titanium complex at different $\mathrm{pH}$}

In the presence of the titanocene complex, a competition between direct and indirect reduction of DMZ occurred as it can be clearly seen by cyclic voltammetry. Indeed, as presented in Fig. 3a, voltammograms showed a reversible system corresponding to $\mathrm{Ti}^{\mathrm{I} / \mathrm{IIII}}$ at $-0.45 \mathrm{~V} / \mathrm{SCE}$ and a reduction peak of DMZ at $-0.3 \mathrm{~V} / \mathrm{SCE}$, corresponding to the formation of hydroxylamine. The catalytic activity of titanocene complex was evidenced by addition of increasing concentrations of DMZ enhancing the reduction peak while the reverse anodic peak decreased. To check if it is possible to favour the catalytic reduction over the direct process and so to decrease the amount of hydroxylamine formed at the electrode, the influence of $\mathrm{pH}$ on both reduction processes was studied. Cyclic voltammetry of titanocene complex in the presence of DMZ was carried out at increasing $\mathrm{pH}$ until 3, since the complex is known to be stable in strong acidic medium $(\mathrm{pH}<$ 4), whereas it loses a cyclopentadienyl group at neutral $\mathrm{pH}$ [38]. The increase of $\mathrm{pH}$ strongly influenced the reduction potential of DMZ as seen in Fig. 2, but not those of titanocene (Eq. (5)). Thus, the DMZ reduction peak was shifted in negative potentials close or lower to the reduction potential of titanocene (Fig. 3 b, c, d). Thus, indirect reduction of DMZ should be favoured at less acidic $\mathrm{pH}$.

\subsubsection{Degradation of DMZ by indirect electrolysis}

Indirect electrolysis of DMZ $\left(100 \mathrm{mg} \mathrm{L}^{-1}\right)$ in the presence of titanocene $\left(20 \mathrm{mg} \mathrm{L}^{-1}\right)$ was carried out at $-0.45 \mathrm{~V} / \mathrm{SCE}$ in the flow electrochemical cell at $\mathrm{pH}=2$ to assure a good solubility of 
DMZ in the medium and limit direct electrolysis leading to the formation of hydroxylamine intermediates. A comparison was made with the same experiment performed at $\mathrm{pH}=0.3$. Flow rate was fixed at $1 \mathrm{~mL} \mathrm{~min}{ }^{-1}$ and the media was constantly saturated with argon to avoid any influence of the dissolved oxygen. UPLC analyses showed a total degradation of DMZ after a single pass through the flow cell for both $\mathrm{pH}$ (conversion yield > 99.9\%). UPLC-MS/MS analyses were performed to compare electrolyses performed at $\mathrm{pH}=0.3$ and 2 and showed the presence of the same five by-products previously observed for direct electrolysis (Fig. 4). Thus, a competition reaction with direct electrolysis occurred at both $\mathrm{pH}$.

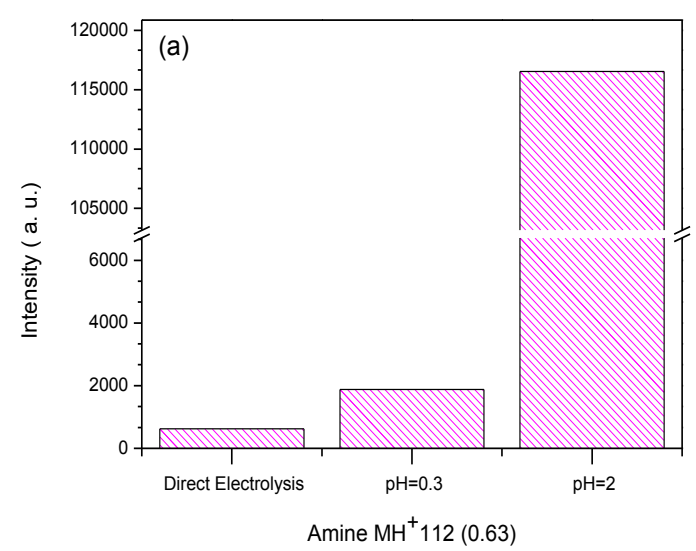

However, the selectivity of the reduction of DMZ in the presence of titanocene dichloride at $\mathrm{pH}=2$ was clearly highlighted by comparison of the peak intensity corresponding to the protonated amine $\left(\mathrm{MH}^{+} 112\right)$ (Fig. 4 a). Indeed, the high intensity of the peak at $\mathrm{pH}=2$ evidenced the effect of $\mathrm{pH}$ on the selectivity of the reaction favouring indirect electrolysis over direct reduction.

However, a competition with direct electrolysis still occurred at $\mathrm{pH}=2$, as shown by the presence of azo $\left(\mathrm{MH}^{+} 219\right)$ and azoxy $\left(\mathrm{MH}^{+} 235\right)$ derivatives. Comparison with indirect electrolysis performed at $\mathrm{pH} 0.3$ seems to show a slight decrease of the amount of azoxy compounds (Fig. $4 \mathrm{c}$ ), due to less hydroxylamine intermediate in the solution (Eq. (2)) and a slight increase of the amount of azo derivative (Fig. 4 b), probably due to the high amount of amine in the medium (Eq. (1)).

\subsubsection{Biological treatment}

In order to confirm the effectiveness of the electrochemical reduction prior a biological treatment, activated sludge culture of pure DMZ $\left(100 \mathrm{mg} \mathrm{L}^{-1}\right)$ and electrolyzed solutions in the absence and in the presence of titanocene $\left(20 \mathrm{mg} \mathrm{L}^{-1}\right)$ at $\mathrm{pH} 0.3$ and 2 were performed. 
The first step of a biological treatment consists to check for possible biosorption on activated sludge. Since biosorption is a rapid phenomenon, it can be observed during few hours. Thus, measurements of the residual concentration of DMZ were monitored during the first 4 hours of activated sludge culture.

As displayed in Fig. 5, the disappearance of DMZ remained low (it did not exceed $10 \%$ removal), showing that DMZ was only slightly biosorbed on activated sludge.

Biological treatment was then carried out by means of activated sludge in which TOC were monitored during 19 days. Evolution of TOC values of non-pre-treated and pre-treated solution is displayed in Fig. 6. For DMZ solution, a low mineralization yield in the first days of culture was observed until day 13 (around $10 \%$ ), due probably to biosorption. During this steady phase, an acclimation period of microorganisms to DMZ occurs, since DMZ is the only available carbon source. From day 13 to the end of culture, $20 \%$ of organic carbon was mineralized, showing an assimilation of a part of the pollutant.

In contrast to non-pre-treated DMZ, an improvement of the mineralization yields was clearly observed during the biological treatment of the electrolyzed solutions, confirming the relevance of the electroreduction pretreatment of dimetridazole prior to a biological process (Fig. 6).

Evolution of mineralization showed an important increase until day 5 for direct electrolysis $(41.5 \% \pm 0.5$ mineralization yield) and indirect electrolysis; this illustrated a readily assimilation of some of the degradation by-products. No significant increase was observed from day 5 until day 13; this period seems to correspond to an acclimation of microorganisms to the most refractory DMZ by-products as in the case of pure DMZ. From day 13 to the end of culture an important increase in mineralization yields was observed. Thus, $75.8 \pm 0.1 \%$ and $77.1 \pm$ $0.4 \%$ decrease of the TOC were recorded for indirect electrolysis at $\mathrm{pH}=2$ and $\mathrm{pH}=0.3$, respectively and $81.2 \pm 0.1 \%$ for direct electrolysis, showing a good assimilation of the reduced by-products by microorganisms. Thus, whereas indirect electrolysis performed at $\mathrm{pH} 2$ was more selective to the formation of the amino derivative than at $\mathrm{pH} 0.3$, the biodegradability of both electrolyzed solutions was similar. Mineralization yields of indirect and direct electrolysis after 19 days were also analogous. However, if the contribution of titanocene (carbon content: $48.2 \%$ ), which was most likely biorecalcitrant, was not taken into account in the TOC amount, mineralization yields for indirect electrolysis would be most certainly significantly higher. The 
biorecalcitrance of titanocene, even after 20 days of activated sludge culture, should be checked to confirm this assumption and hence to determine the actual mineralization yields.

\section{Conclusions}

In this work, the feasibility of coupling an electroreduction pretreatment prior to a biological process for the removal of dimetridazole was investigated. Direct electrolysis was first carried out at low potential to minimize the formation of amino derivatives and then the formation of azo dimer. A total degradation of dimetridazole was obtained (conversion yield $=99.5 \%$ ) and the $\mathrm{BOD}_{5} / \mathrm{COD}$ ratio increased from 0.13 to 0.24 . Indirect electrolysis was then investigated at various $\mathrm{pH}$ to favour the formation of amino compounds over hydroxylamines and then to prevent the formation of azo and azoxy dimers. Although UPLC-MS/MS analyses showed the presence of dimers for all electrolyzed solutions, a higher selectivity to the formation of the amino compound was clearly evidenced for indirect electrolyses performed at $\mathrm{pH} 2$. The enhancement of the biodegradability was clearly shown during the biological treatment, since mineralization yields of all electrolyzed solutions increased significantly. $81 \%$ of the total organic carbon TOC was removed in direct electrolysis, and indirect electrolyses led to $75.8 \%$ and $77.1 \%$ mineralization yields at $\mathrm{pH}=2$ and $\mathrm{pH}=0.3$, respectively. However, the actual mineralization yields should be most certainly significantly higher if the contribution of titanocene, which is probably biorecalcitrant, is not taken into account in the TOC amount. Thus, the immobilization of the catalyst on the surface will be considered in further work to avoid this bias and hence to improve the total mineralization yield.

\section{References}

[1] M. Klavarioti, D. Mantzavinos, D. Kassinos, Removal of residual pharmaceuticals from aqueous systems by advanced oxidation processes, Environ Int, 35 (2009) 402-417.

[2] S. Castiglioni, R. Bagnati, R. Fanelli, F. Pomati, D. Calamari, E. Zuccato, Removal of pharmaceuticals in sewage treatment plants in Italy, Environ. Sci. Technol., 40 (2006) 357-363. [3] H.A. Duong, N.H. Pham, H.T. Nguyen, T.T. Hoang, H.V. Pham, V.C. Pham, M. Berg, W. Giger, A.C. Alder, Occurrence, fate and antibiotic resistance of fluoroquinolone antibacterials in hospital wastewaters in Hanoi, Vietnam, Chemosphere, 72 (2008) 968-973.

[4] B. Halling-Sorensen, Inhibition of aerobic growth and nitrification of bacteria in sewage sludge by antibacterial agents, Arch. Environ. Contam. Toxicol., 40 (2001) 451-460.

[5] K. Kümmerer, The presence of pharmaceuticals in the environment due to human use present knowledge and future challenges, J. Environ. Manage., 90 (2009) 2354-2366. 
[6] T. Heberer, Tracking persistent pharmaceutical residues from municipal sewage to drinking water, J. Hydrol., 266 (2002) 175-189.

[7] R. Andreozzi, V. Caprio, R. Marotta, A. Radovnikovic, Ozonation and H2O2/UV treatment of clofibric acid in water: a kinetic investigation, J. Hazard. Mater., 103 (2003) 233-246.

[8] R. Andreozzi, V. Caprio, R. Marotta, D. Vogna, Paracetamol oxidation from aqueous solutions by means of ozonation and H2O2/UV system, Water Res., 37 (2003) 993-1004.

[9] T.A. Ternes, M. Meisenheimer, D. McDowell, F. Sacher, H.J. Brauch, B.H. Gulde, G. Preuss, U. Wilme, N.Z. Seibert, Removal of pharmaceuticals during drinking water treatment, Environ. Sci. Technol., 36 (2002) 3855-3863.

[10] D. Mansour, F. Fourcade, I. Soutrel, D. Hauchard, N. Bellakhal, A. Amrane, Relevance of a combined process coupling electro-Fenton and biological treatment for the remediation of sulfamethazine solutions - Application to an industrial pharmaceutical effluent, C. R. Chim., 18 (2015) 39-44.

[11] Y. Lan, C. Coetsier, C. Causserand, G. Serrano Karine, Feasibility of Micropollutants Treatment by Coupling Nanofiltration and Electrochemical Oxidation: Case of Hospital Wastewater, Int. J. Chem. Reactor Eng., 13 (2015) 153-159.

[12] K. Kümmerer, A. Al-Ahmad, V. Mersch-Sundermann, Biodegradability of some antibiotics, elimination of the genotoxicity and affection of wastewater bacteria in a simple test, Chemosphere, 40 (2000) 701-710.

[13] J. Rivera-Utrilla, M. Sanchez-Polo, M.A. Ferro-Garcia, G. Prados-Joya, R. Ocampo-Perez, Pharmaceuticals as emerging contaminants and their removal from water. A review, Chemosphere, 93 (2013) 1268-1287.

[14] A. Göbel, C.S. McArdell, A. Joss, H. Siegrist, W. Giger, Fate of sulfonamides, macrolides, and trimethoprim in different wastewater treatment technologies, Sci. Total Environ., 372 (2007) 361-371.

[15] S. Yahiat, F. Fourcade, S. Brosillon, A. Amrane, Photocatalysis as a pre-treatment prior to a biological degradation of cyproconazole, Desalination, 281 (2011) 61-67.

[16] I. Yahiaoui, F. Aissani-Benissad, F. Fourcade, A. Amrane, Removal of a mixture tetracycline-tylosin from water based on anodic oxidation on a glassy carbon electrode coupled to activated sludge, Environ. Technol., 36 (2015) 1837-1846.

[17] C. Annabi, F. Fourcade, I. Soutrel, F. Geneste, D. Floner, N. Bellakhal, A. Amrane, Degradation of enoxacin antibiotic by the electro-Fenton process: Optimization, biodegradability improvement and degradation mechanism, J. Environ. Manage., 165 (2016) 96-105. 
[18] S. Hammami, N. Bellakhal, N. Oturan, M.A. Oturan, M. Dachraoui, Degradation of Acid Orange 7 by electrochemically generated $(\mathrm{OH})$-O-center dot radicals in acidic aqueous medium using a boron-doped diamond or platinum anode: A mechanistic study, Chemosphere, 73 (2008) 678-684.

[19] M.J. Farré, M.I. Maldonado, W. Gernjak, I. Oller, S. Malato, X. Domènech, J. Peral, Coupled solar photo-Fenton and biological treatment for the degradation of diuron and linuron herbicides at pilot scale, Chemosphere, 72 (2008) 622-629.

[20] S. Parra, S. Malato, C. Pulgarin, New integrated photocatalytic-biological flow system using supported $\mathrm{TiO} 2$ and fixed bacteria for the mineralization of isoproturon, Appl. Catal. B: Environ., 36 (2002) 131-144.

[21] G. Prados-Joya, M. Sánchez-Polo, J. Rivera-Utrilla, M. Ferro-garcía, Photodegradation of the antibiotics nitroimidazoles in aqueous solution by ultraviolet radiation, Water Res., 45 (2011) 393-403.

[22] H.W. Leung, L. Jin, S. Wei, M.M. Tsui, B. Zhou, L. Jiao, P.C. Cheung, Y.K. Chun, M.B. Murphy, P.K. Lam, Pharmaceuticals in tap water: human health risk assessment and proposed monitoring framework in China, Environ Health Perspect, 121 (2013) 839-846.

[23] J. Rivera-Utrilla, G. Prados-Joya, M. Sánchez-Polo, M.A. Ferro-García, I. BautistaToledo, Removal of nitroimidazole antibiotics from aqueous solution by adsorption/bioadsorption on activated carbon, J. Hazard. Mater., 170 (2009) 298-305.

[24] M. Badia-Fabregat, D. Lucas, M.A. Pereira, M. Alves, T. Pennanen, H. Fritze, S. Rodríguez-Mozaz, D. Barceló, T. Vicent, G. Caminal, Continuous fungal treatment of nonsterile veterinary hospital effluent: pharmaceuticals removal and microbial community assessment, Appl. Microbiol. Biotechnol., 100 (2016) 2401-2415.

[25] N.A. Salles, F. Fourcade, F. Geneste, D. Floner, A. Amrane, Relevance of an electrochemical process prior to a biological treatment for the removal of an organophosphorous pesticide, phosmet, J. Hazard. Mater., 181 (2010) 617-623.

[26] J.M. Fontmorin, S. Huguet, F. Fourcade, F. Geneste, D. Floner, A. Amrane, Electrochemical oxidation of 2,4-Dichlorophenoxyacetic acid: Analysis of by-products and improvement of the biodegradability, Chem. Eng. J., 195 (2012) 208-217.

[27] I. Saidi, I. Soutrel, F. Fourcade, A. Amrane, D. Floner, N. Bellakhal, F. Geneste, Flow electrolysis on high surface electrode for biodegradability enhancement of sulfamethazine solutions, J. Electroanal. Chem., 707 (2013) 122-128. 
[28] D. Belkheiri, F. Fourcade, F. Geneste, D. Floner, H. Ait-Amar, A. Amrane, Feasibility of an electrochemical pre-treatment prior to a biological treatment for tetracycline removal, Sep. Purif. Technol., 83 (2011) 151-156.

[29] I. Saidi, I. Soutrel, D. Floner, F. Fourcade, N. Bellakhal, A. Amrane, F. Geneste, Indirect electroreduction as pretreatment to enhance biodegradability of metronidazole, J. Hazard. Mater., 278 (2014) 172-179.

[30] J.C. Spain, Biodegradation of nitroaromatic compounds Annu. Rev. Microbiol, 94 (1995) $523-555$.

[31] D. Floner, L. Laglaine, C. Moinet, Indirect electrolysis involving an ex-cell two-phase process. Reduction of nitrobenzenes with a titanium complex as mediator, Electrochim. Acta, 42 (1997) 525-529.

[32] C.Moinet, Electrosynthèse organique en continu. Méthodes directes et indirectes, J.Phys, 4 (1994) 175-184.

[33] M. Crosson, R. Gibb, Microscale experiments: Dissolved oxygen and chloride determination in water, J. Chem. Educ., 69 (1992) 830-832.

[34] C. Hu, J. Deng, X. Xiao, X. Zhan, K. Huang, N. Xiao, S. Ju, Determination of dimetridazole using carbon paste electrode modified with aluminum doped surface molecularly imprinted siloxane, Electrochim. Acta, 158 (2015) 298-305.

[35] M.A. La-Scalea, S.H.P. Serrano, I.G.R. Gutz, Voltammetric behaviour of metronidazole at mercury electrodes, J. Braz. Chem. Soc., 10 (1999) 127-135.

[36] C. Pulgarin, M. Invernizzi, S. Parra, V. Sarria, R. Polania, P. Peringer, Strategy for the coupling of photochemical and biological flow reactors useful in mineralization of biorecalcitrant industrial pollutants, Catal. Today, 54 (1999) 341-352.

[37] D. Dumanovic, J. Jovanovic, S. Popovic, D. Kosanovic, The solubility of some 4(5)- and 5-nitroimidazoles in water and twenty common organic solvents, J. Serb. Chem. Soc., 51 (1986) 411-416.

[38] G. Mokdsi, M.M. Harding, Water soluble, hydrolytically stable derivatives of the antitumor drug titanocene dichloride and binding studies with nucleotides, J. Organomet. Chem., 565 (1998) 29-35.

[39] J.H. Toney, T.J. Marks, Hydrolysis chemistry of the metallocene dichlorides M(ๆ5$\mathrm{C} 5 \mathrm{H} 5) 2 \mathrm{Cl} 2, \mathrm{M}=\mathrm{Ti}, \mathrm{V}, \mathrm{Zr}$. Aqueous kinetics, equilibria, and mechanistic implications for a new class of antitumor agents, J. Am. Chem. Soc., 107 (1985) 947-953. 


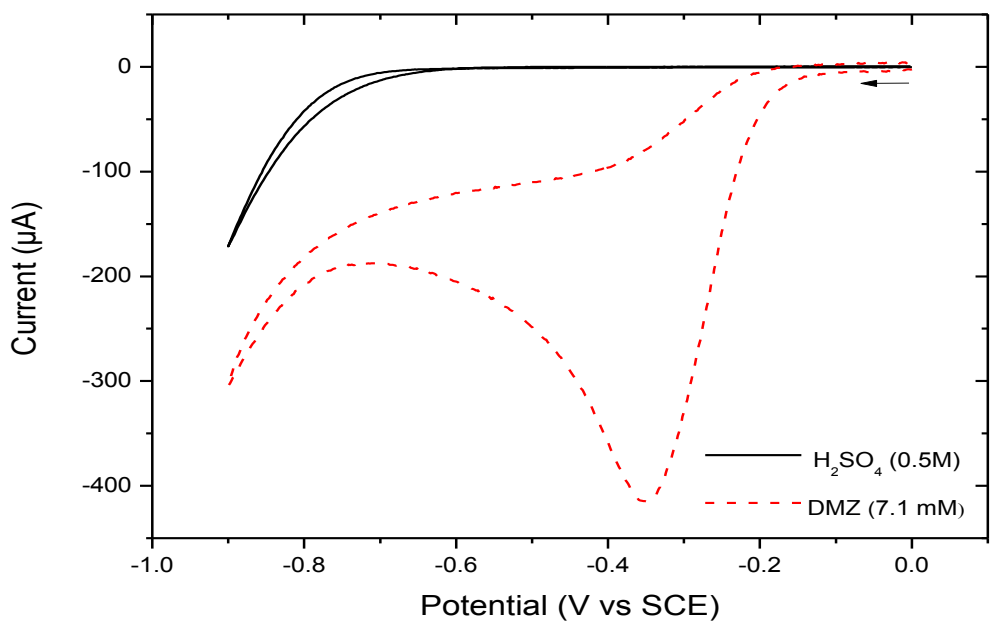

Fig. 1. Voltammograms recorded in $0.5 \mathrm{M} \mathrm{H}_{2} \mathrm{SO}_{4}$ without (-) and with (-----) $100 \mathrm{mg} \mathrm{L}^{-1}(7.1 \mathrm{mM}) \mathrm{DMZ}$ on a glassy carbon electrode $\left(7 \mathrm{~mm}^{2}\right)$, under argon atmosphere. Scan rate: $100 \mathrm{mV} \mathrm{s}^{-1}$.

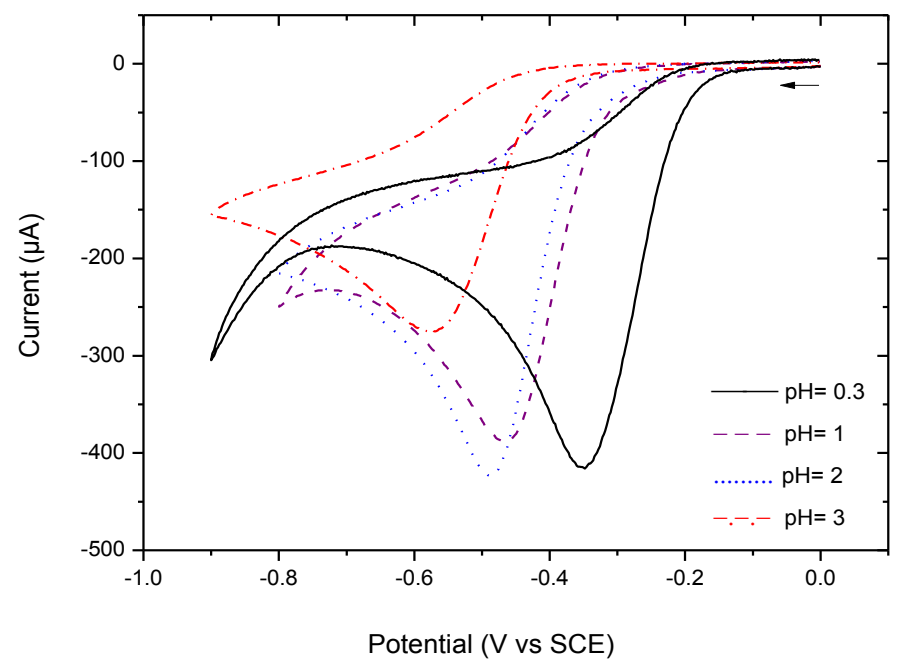

Fig. 2. Voltammograms of a DMZ solution $\left(100 \mathrm{mg} \mathrm{L}^{-1}\right)$ in $\mathrm{H}_{2} \mathrm{SO}_{4}$ at $\mathrm{pH}=0.3,1,2,3$ on a glassy carbon electrode $\left(7 \mathrm{~mm}^{2}\right)$, under argon atmosphere. Scan rate: $100 \mathrm{mV} \mathrm{s}^{-1}$. 

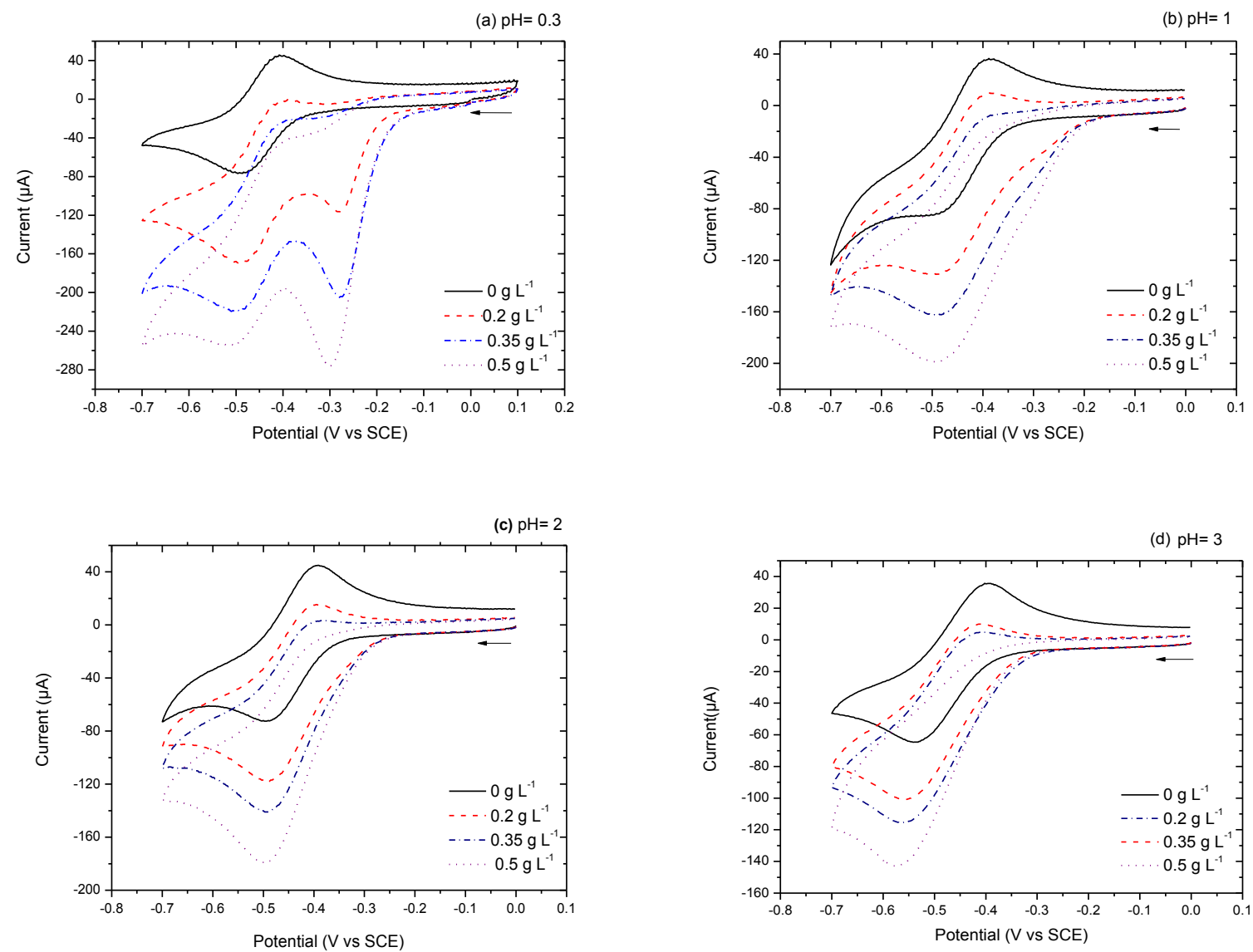

Fig. 3. Voltammograms of the titanium complex $\left(100 \mathrm{mg} \mathrm{L}^{-1}\right)$ in aqueous acidic medium $\mathrm{H}_{2} \mathrm{SO}_{4}$ at different $\mathrm{pH}$ : a) 0.3 , b) 1 , c) 2 , d) 3 in the absence $(-)$ and in the presence of $0.2(----), 0.35(---)$ and $0.5 \mathrm{~g} \mathrm{~L}^{-1}(\ldots \ldots)$. Voltammograms were recorded at $100 \mathrm{mV} \mathrm{s}^{-1}$.
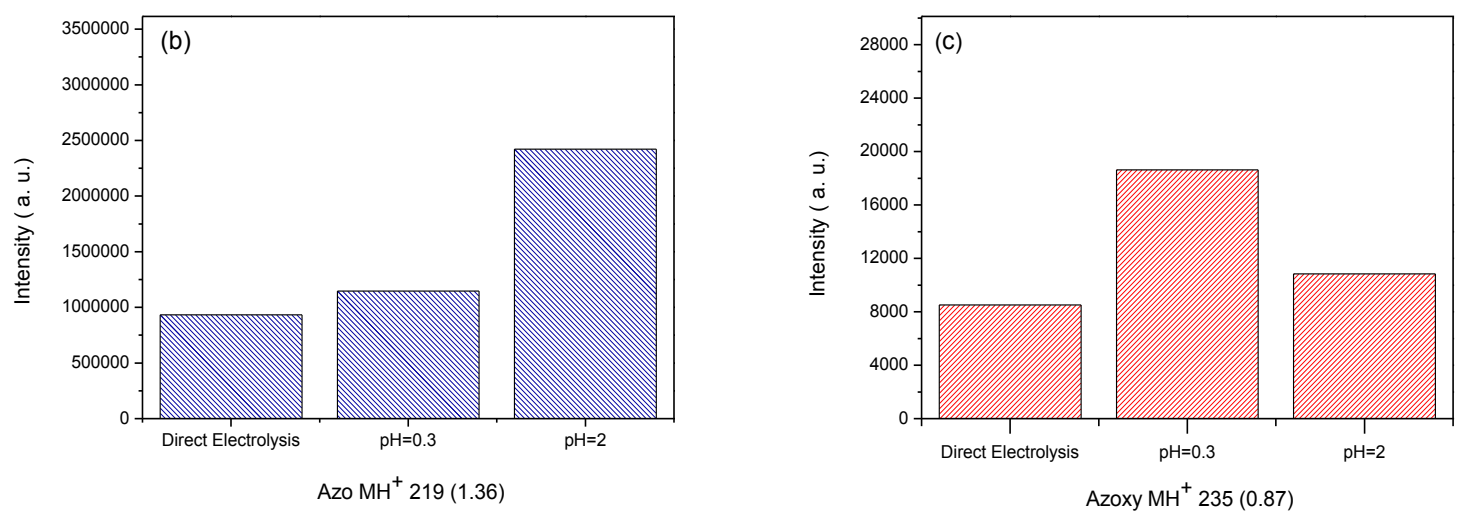

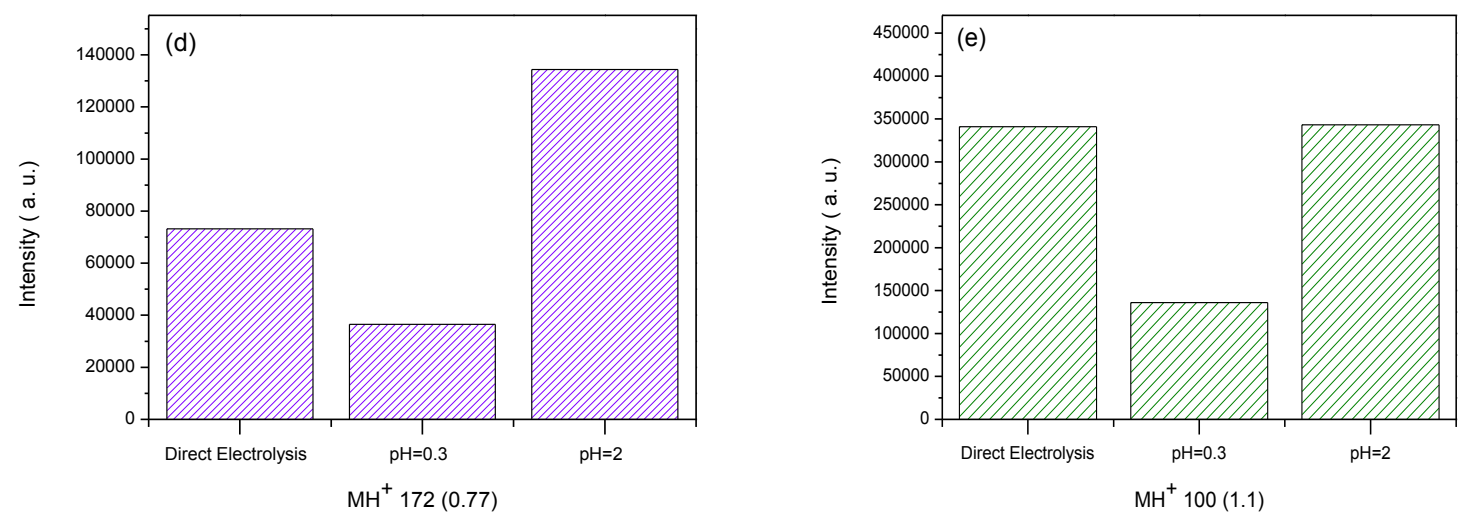

Fig. 4. UPLC-MS/MS analysis of electrolytic medium after DMZ reduction performed in the absence and in the presence of $20 \mathrm{mg} \mathrm{L}^{-1}$ of $\left(\mathrm{C}_{5} \mathrm{H}_{5}\right)_{2} \mathrm{TiCl}_{2}$ at $\mathrm{pH}=0.3$ and $\mathrm{pH}=2$.

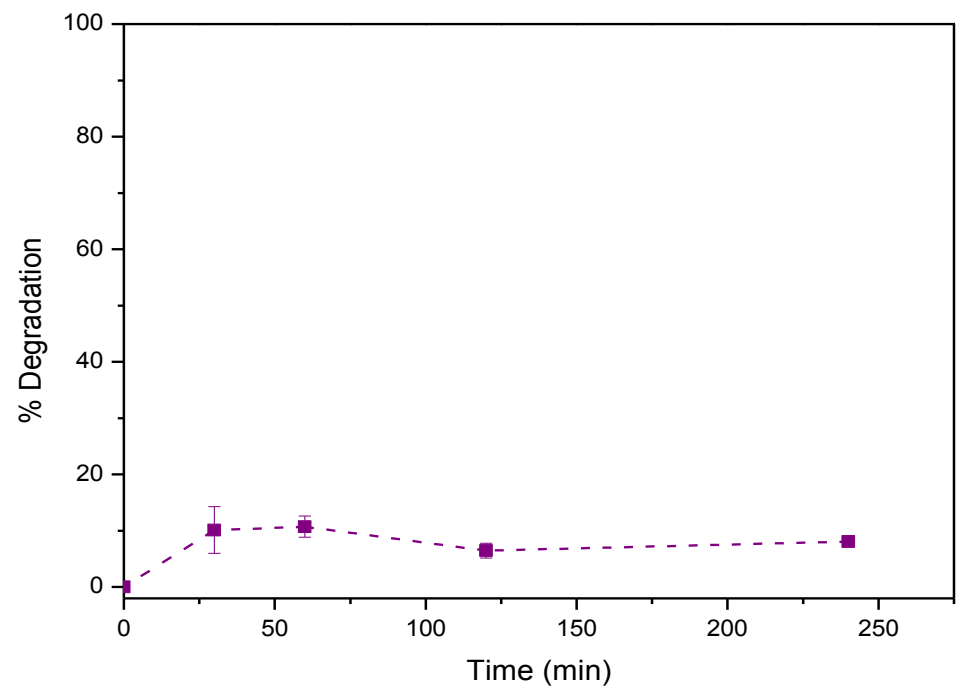

Fig. 5. Time-course of degradation during biosorption on activated sludge $\left(0.5 \mathrm{~g} \mathrm{~L}^{-1}\right)$ of DMZ solution (100 $\left.\mathrm{m} \mathrm{L}^{-1}\right)$. Error bars are based on 2 reproducibility measurements. 


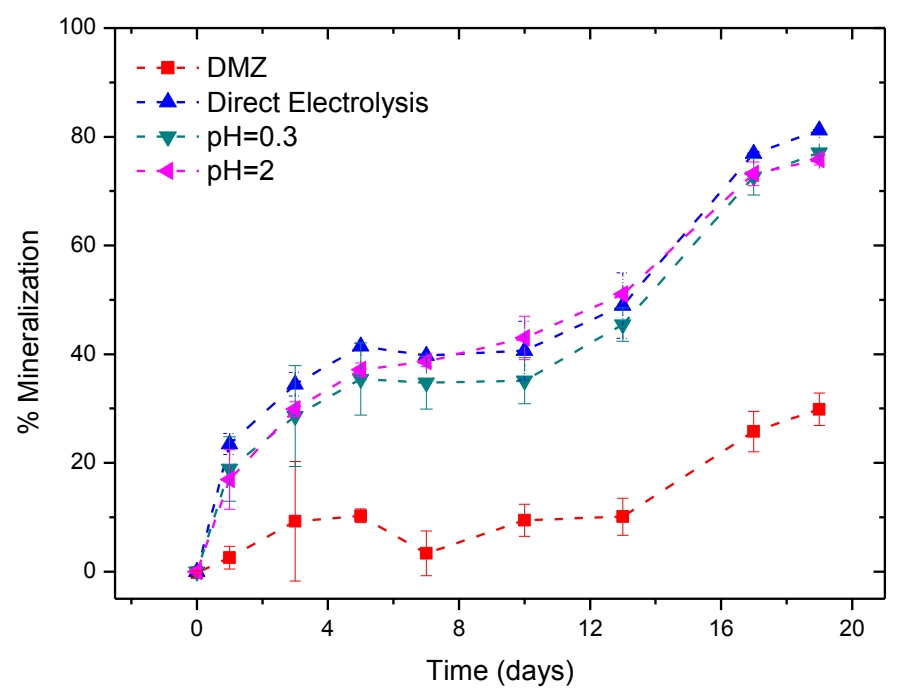

Fig. 6. Time-courses of mineralization during activated sludge culture on DMZ solution (100 $\mathrm{mg} \mathrm{L}^{-1}$, $\left.\mathrm{H}_{2} \mathrm{SO}_{4} \mathrm{pH}=0.3\right)(-\boldsymbol{m}-)$ and DMZ solutions electrolyzed in the absence $(\mathrm{pH}=0.3)(-\boldsymbol{\Delta}-)$ and in the presence of $20 \mathrm{mg} \mathrm{L}^{-1}$ of $\left(\mathrm{C}_{5} \mathrm{H}_{5}\right)_{2} \mathrm{TiCl}_{2}$ at $\mathrm{pH}=0.3(-\boldsymbol{\nabla}$-) and $\mathrm{pH}=2$ (- - -). Error bars are based on 2 reproducibility measurements.

\section{Table 1}

Physico-chemical properties of dimetridazole (DMZ).

Structure

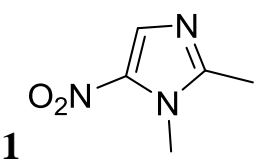

Molecular Formula

$\mathrm{C}_{5} \mathrm{H}_{7} \mathrm{~N}_{3} \mathrm{O}_{2}$

$\mathrm{M}_{\mathrm{w}}\left(\mathrm{g} \mathrm{mol}^{-1}\right)$

$\mathrm{S}_{\mathrm{w}}\left(\mathrm{mol} \mathrm{L}^{-1}\right)$

$\mathrm{pK}_{\mathrm{a}}$

In recent years, electrochemical oxidation/reduction of recalcitrant pollutants coupled to biological treatment has been considered as an alternative process. These former techniques rarely lead to a total mineralisation, which is particularly interesting for a coupling with a biological treatment. Several studies reported the efficiency of these electrochemical pretreatment for the removal of recalcitrant molecules such as phosmet an organophosphorous insecticide [25], a chlorinated phenoxy herbicide 2,4-dichlorophenoxyacetic acid [26] and extensively used antibiotics such as sulfamethazine [27] and tetracycline [28]. 
More recently, the coupling of an electrochemical reduction process (direct/indirect) with a biological treatment has been reported for the removal of metronidazole, a nitroimidazole antibiotic of the same family as dimetridazole [29]. These compounds contain nitro groups, which are known to reduce the biodegradability of the molecule [30]. The reduction of nitro groups into amino compounds should increase the biodegradability allowing a rapid and efficient biological treatment. However, direct electrochemical reduction of $\mathrm{NO}_{2}$ is known to go through hydroxylamine intermediates responsible for the formation of azo and azoxy dimers by reaction with their amino (Scheme 1, Equation 1) and nitroso (Scheme 1, Equation 2) derivatives, respectively [29].

$$
\begin{aligned}
& \mathrm{RNH}_{2}+\mathrm{R}^{\prime} \mathrm{NHOH} \longrightarrow \mathrm{RN}=\mathrm{NR}^{\prime} \\
& \mathrm{R}^{\prime} \mathrm{NHOH} \stackrel{\mathrm{O}_{2}}{\longrightarrow} \mathrm{R}^{\prime} \mathrm{NO} \\
& \mathrm{R}^{\prime} \mathrm{NO}+\mathrm{RNHOH} \longrightarrow \mathrm{O}_{-}^{\mathrm{R}^{\prime}} \stackrel{+}{=} \mathrm{NR}+\mathrm{H}_{2} \mathrm{O}
\end{aligned}
$$

Scheme 1. Formation of azo and azoxy dimers

Indirect electrochemical reduction of metronidazole [31] has been investigated in the presence of titanocene dichloride $\left(\left(\mathrm{C}_{5} \mathrm{H}_{5}\right)_{2} \mathrm{TiCl}_{2}\right)$, known as catalyst for the selective reduction of nitro groups into amino compounds. Titanium complex allowed a reduction process at less cathodic potential and could offer higher selectivity than direct electrolysis, decreasing the amount of by-products due to the formation of hydroxylamine intermediates. Thus indirect electrolysis coupled with a biological treatment led to an improvement of biodegradability, since $85 \%$ of the total organic carbon was removed, underlining the interest of the $\mathrm{NO}_{2}$ reduction to improve biodegradability [29]. However, the formation of dimers due to a competition reaction with direct electrolysis still occurred that prevented total mineralization.

In this work, the method was extended to dimetridazole with the aim to reduce the nitro derivative into more biodegradable by-products before implementing a biological process. The intention was to reduce the formation of azo and/or azoxy dimers and evaluate the biodegradability of such electrolyzed solutions. For this purpose, two different ways were investigated i) A direct electrochemical reduction carried out at low potentials to avoid the formation of amino derivatives and then the formation of azo dimer. ii) An indirect electrochemical reduction performed at different $\mathrm{pH}$ to favour the formation of amino compounds over hydroxylamines in order to prevent the formation of azo and azoxy dimers. 
For both direct and indirect electrolyses, by-products were identified and biodegradability was determined.

\section{Materials and methods}

\subsection{Chemicals and materials}

Dimetridazole (DMZ - purity $>97 \%)$ and titanocene dichloride $\left(\mathrm{C}_{5} \mathrm{H}_{5}\right)_{2} \mathrm{TiCl}_{2}$ were obtained from TCI (Tokyo Chemical Industry). $\mathrm{H}_{2} \mathrm{SO}_{4}$ (purity 95\%) was purchased from VWR (Van Water \& Rogers). Graphite felt (Recycled Vein Graphite RVG 4000) was supplied by Mersen (France). Its specific area measured by the BET (Brunauer, Emett and Teller) method, its volume density and its carbon content were $0.7 \mathrm{~m}^{2} \mathrm{~g}^{-1}, 0.088 \mathrm{~g} \mathrm{~cm}^{-3}$ and $99.9 \%$, respectively.

\subsection{Materials for electrochemical pretreatment}

Electrochemical pretreatment, in continuous system, was performed in a home-made flow cell [32]. Two PAPYEX carbon papers supplied by Mersen (France) were interconnected and used as counter electrode $(85 \mathrm{~mm} \times 85 \mathrm{~mm})$. Compartments were separated by cationic exchange membranes (Ionac 3470 - Lanxess SAS, Courbevoie, France). The reference electrode (saturated calomel electrode - SCE) was positioned in the middle of the graphite felt (48 mm diameter and $12 \mathrm{~mm}$ width) used as working electrode. VersaSTAT3 AMETEK Model (Princeton Applied Research) potentiostat/galvanostat was used for the potential control. The solution (100 mg L $\mathrm{m}^{-1} \mathrm{DMZ}$ in aqueous acidic medium $\mathrm{H}_{2} \mathrm{SO}_{4}$ ) percolated the porous electrode

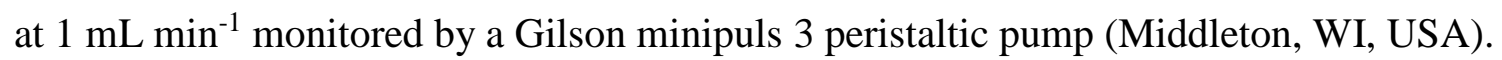

\subsection{Biological treatment}

Activated sludge used in this study was obtained from a local wastewater treatment plant (Rennes Beaurade, France). To remove any residual carbon and mineral source, the sludge was washed five times with tap water and distilled water and centrifuged at $3000 \mathrm{rpm}$ for $10 \mathrm{~min}$. Cultures were carried out at least in duplicates at $25^{\circ} \mathrm{C}$ in $500 \mathrm{~mL}$ Erlenmeyer flasks containing $250 \mathrm{~mL}$ of medium with $0.5 \mathrm{~g} \mathrm{~L}^{-1}$ of activated sludge. The following mineral basis was used for all experiments $\left(\mathrm{mg} \mathrm{L} \mathrm{L}^{-1}\right): \mathrm{Na}_{2} \mathrm{HPO}_{4} \cdot 2 \mathrm{H}_{2} \mathrm{O}, 154.4 ; \mathrm{KH}_{2} \mathrm{PO}_{4}, 85, \mathrm{~K}_{2} \mathrm{HPO}_{4}, 208$, $\mathrm{MgSO}_{4} \cdot 7 \mathrm{H}_{2} \mathrm{O}, 22.6 ; \mathrm{CaCl}_{2}, 27.6 ; \mathrm{NH}_{4} \mathrm{Cl}, 75$ and $\mathrm{FeCl}_{3} .6 \mathrm{H}_{2} \mathrm{O}, 0.26$. The $\mathrm{pH}$ was then adjusted to 7.0 with $\mathrm{NaOH}$ solution. Samples $(3.5 \mathrm{~mL})$ were taken regularly for TOC and HPLC measurements and filtered on $0.45 \mu \mathrm{m}$. $\mathrm{pH}$ measurements were carried out using a Hanna $\mathrm{pH}$ metre with a combined micro-electrode probe (thermo Spectronic, Rochester, USA). 
Table 2.

COD, BOD 5 and biodegradability of DMZ $\left(100 \mathrm{mg} \mathrm{L}^{-1}\right)$ and electrolyzed solution $\left(\mathrm{E}=-0.45 \mathrm{~V} / \mathrm{SCE}, 1 \mathrm{~mL} \mathrm{~min}^{-1}\right)$

\begin{tabular}{llll}
\hline Sample & $\mathrm{COD}\left(\mathrm{mg} \mathrm{O}_{2} \mathrm{~L}^{-1}\right)$ & $\mathrm{BOD}_{5}\left(\mathrm{mg} \mathrm{O}_{2} \mathrm{~L}^{-1}\right)$ & $\mathrm{BOD}_{5} / \mathrm{COD}$ \\
\hline DMZ solution & $93.5 \pm 2.1$ & $12.0 \pm 0.0$ & $0.13 \pm 0.00$ \\
Electrolyzed solution & $158.0 \pm 2.8$ & $38.5 \pm 0.7$ & $0.24 \pm 0.01$ \\
\hline
\end{tabular}

